\title{
PENERAPAN SCAFFOLDING LEARNING BERBASIS KARAKTER DALAM MENINGKATAN HASIL BELAJAR MATERI EKSPONEN DAN LOGARITMA KELAS X.1 PADA SEMESTER 1 SMAN 1 TANJUNG TAHUN PELAJARAN 2014/2015
}

\author{
Winarno \\ Guru Matematika, SMAN 1 Tanjung - Brebes \\ Jalan Cemara No.1 Lemahabang, Tanjung, Brebes 52254 \\ email:winarno32@gmail.com
}

\begin{abstract}
Abstrak
Penelitian ini bertujuan untuk meningkatkan hasil belajar materi Eksponen dan Logaritma dengan penerapan scaffolding learning berbasis karakter kelas X.1 pada semester 1 SMAN 1 Tanjung tahun pelajaran 2014/2015. Hasil belajar dalam penelitian mencakup tiga aspek, yakni (1) afektif, berupa variabel karakter kemandirian, (2) psikomotorik, variabel keterampilan pemecahan masalah, dan (3) kognitif, prestasi belajar siswa. Data penelitian menggunakan data primer dan sekunder dengan teknik tes berupa tes uraian dan teknik non tes berupa pengmatan karakter kemandirian dan keterampilan pemecahan masalah siswa. Analisis yang digunakan deskriptif komparatif untuk membandingkan antara nilai awal dan hasil yang dicapai dengan indikator keberhasilan 85\%. Hasil analisis menunjukan bahwa hasil belajar dengan KKM adalah 75 pada kondisi awal diperoleh 51,28\% dari 39 siswa. Hasil siklus I karakter kemandirian 64,10\%, keterampilan pemecahan masalah 53,85\%, dan prestasi belajar 61,54\%. Siklus II berturut-turut 89,75\%, 87,18\%, dan $87,18 \%$. Peningkatan karakter kemandirian sebesar 25,65\%, keterampilan pemecahan masalah 33,33\%, dan prestasi belajar $25,64 \%$.
\end{abstract}

Kata kunci: scaffolding, karakter kemandirian, keterampilan pemecahan masalah

Abstract

The objective of this research is to improve the learning outcomes of Exponential and Logarithmic through character-based scaffolding learning of class X.1 of SMA Negeri 1 Tanjung Semester 1 in the academic year of 2014/2015. The learning outcomes in this research include three aspects, (1) affective, sel-reliance characters variables; (2) psychomotoric, problem solving skills variables; and (3) cognitive, students' learning achievement. The primary and secondary data were used in this research.The data were gained from technique test in the form of essay test and non-test technique in the form of students' sel-reliance characters and problem solving skills observation. The descriptive comparative analysis is used to compare the result of the pre-test and the post-test score with the key performance indicator $85 \%$. The result of analysis showed that the learning result with the Minimum Mastery Criteria of 75 at the pre-test was 51,28\% from 39 students. Result of Cycle I was $64,10 \%$ for self-reliance character, 53,85\% for problem solving skill, and 61,54\% learning achievement. Cycle II was $89.75 \%, 87.18 \%$, and $87.18 \%$. The increasing of self-reliance character $25.65 \%$, problem solving skills $33.33 \%$, and learning achievement $25.64 \%$.

Keywords: scaffolding, self-reliance character, problem solving skills

\section{PENDAHULUAN}

Matematika merupakan salah satu rumpun ilmu yang bersifat abstrak dan dinamis. Abstraknya matematika menjadikan sebagian besar siswa mengalami kejenuhan serta kesulitan dalam mempelajarinya. Hal ini dapat dilihat dari hasil belajar siswa yang tidak optimal. Kedinamisan matematika menuntut para pendidik untuk selalu berinovasi agar pembelajaran matematika menjadi lebih menarik dan disukai oleh siswa, sehingga mampu mengangkat hasil belajar siswanya.
Guru dalam membelajarkan matematika seyogyanya berupaya untuk senantiasa mempertimbangkan perkembangan matematika, baik penerapan, penggunaannya, maupun untuk menyelesaikan permasalahan dalam kehidupan sehari-hari.

Pembelajaran akan lebih bermakna bila guru mampu menciptakan kondisi belajar yang dapat membangun kreatifitas siswa untuk menguasai ilmu pendidikan (Sagala, 2006). Dari difinisi ini, tersirat bahwa tugas guru matematika salah satunya adalah membangkitkan kreatfifitas siswanya dalam mempelajari matematika, sehingga jargon 
bahwa matematika sebagai mata pelajaran yang sulit dapat tereliminir.

Salah satu persoalan yang dihadapi para guru dalam pembelajaran matematika adalah prestasi belajar matematika siswa yang masih rendah. Hal ini disebabkan banyak faktor, diantaranya adalah pembelajaran masih konvensional berjalan searah yang cenderung membosankan. Materi Eksponen dan Logaritma adalah salah satu diantara pelajaran matematika kelas X pada semsester gasal yang tidak sedikit siswa mengalami kesulitan, karena kebanyakan soal-soalnya yang kompleks dan membutuhkan pemahaman masalah yang baik.

Prestasi matematika yang kurang optimal pada meteri ini terjadi juga pada siswa di SMA Negeri 1 Tanjung. Data kondisi awal untuk materi eksponen menunjukkan hasil yang tidak memuaskan, di mana masih banyak siswa yang mendapatkan hasil di bawah standar yang ditentukan. Hal ini dibuktikan dari 39 siswa yang ada dalam kelas X.1 baru 20 siswa (51,28\%) yang sudah mencapai ketuntasan dengan $\mathrm{KKM}=75$. Kondisi ini dapat disebabkan karena penggunaan metode yang kurang efektif dan pembelajaran cenderung bejalan searah dan monoton, sehingga siswa menjadi tidak bergairah dalam kegiatan pembelajaran yang berlangsung. Untuk mengatasi permasalahan ini, peneliti mencoba menerapkan strategi pembelajaran yang dapat merangsang siswa dalam belajar matematika, khususnya dalam mempelajari materi Eksponen dan Logaritma. Disamping itu, peneliti juga mencoba menerapkan pembelajaran yang menarik dan menyenangkan yang dapat meningkatkan motivasi serta mengaktifkan siswa dalam belajar. Salah satu teknik tersebut adalah pembelajaran dengan pendekatan scaffolding berbasis karakter. Scaffolding menggambarkan cara belajar anak-anak yang dapat didukung, dengan berangsur dukungan tersebut dihilangkan ketika anak dapat belajar secara mandiri (Anghileri, 2006). Skenario pembelajarannya dimulai dari penataan lingkungan belajar, memberi penjelasan dengan mengecek penyelesaian tugas, kerja kelompok, melakukan refleksi, presentasi, dan penutup. Teknik ini membentuk siswa semakin bertanggungjawab terhadap pembelajarannya sendiri serta membentuk pemahaman konsep menjadi lebih baik karena berdasarkan hasil belajarnya, yang pada akhirnya mampu meningkatkan karakter kemandirian, keterampilan pemecahan masalah, dan prestasi belajar siswa.

\section{KAJIAN PUSTAKA}

Belajar dan pembelajaran dalam matematika tidak hanya sekedar siswa dapat menyelesaikan sebuah tugas dimana mereka menghubungkan antara permasalahan dan gagasan-gagasan baru, namun juga upaya untuk mempertahankan respon siswa agar selalu terlibat dalam proses pembelajaran (Herbst, 2006). Dengan demikian berpikir dan aktif dalam kegiatan pembelajaran merupakan bagian dari proses pembelajaran.

Pembelajaran merupakan kegiatan guru secara terprogramkandalam desain instruksional untuk membuat siswa belajar secara aktif yang menekankan pada penyediaan sumber belajar (Dimyati dan Mudjiono, 1999). Hal ini terlihat jelas bahwa dalam proses pembelajaran guru harus mampu menjadi fasilitator yang baik sebagai trasformasi kemampuan life skill kepada para siswanya.

Pembelajaran matematika merupakan suatu proses atau kegiatan guru mata pelajaran matematika dalam mengajarkan matematika kepada peserta didiknya (Suyitno \& Amin, 2004). Fungsi mata pelajaran matematika adalah sebagai alat, pola pikir, dan ilmu atau pengetahuan (Suherman dkk, 2003). Yang dimaksud pelajaran matematika sebagai alat adalah, siswa diberi pengalaman menggunakan matematika sebagai alat untuk memahami atau menyampaikan suatu informasi, misalnya melalui persamaanpersamaan, atau tabel-tabel dalam model matematika yang merupakan penyederhanaan dari soal cerita atau soal-soal uraian matematika lainnya.

Bagi para siswa belajar matematika juga merupakan pembentukan pola pikir dalam pemahaman suatu pengertian maupun dalam penalaran suatu hubungan diantara pengertian-pengertian itu. Dalam pembelajaran matematika, para siswa dibiasakan untuk memperoleh pemahaman melalui pengalaman tentang sifat-sifat yang dimiliki dan yang tidak dimiliki dari sekumpulan objek (abstraksi).

Hasil belajar adalah perubahan perilaku secara keseluruhan bukan hanya salah satu aspek potensi kemanusiaan saja, namun hasil secara komprehensif. Yang berarti terdapat perubahan pola-pola perbuatan, nilai-nilai, pengertian-pengertian, sikap-sikap, apresiasi dan keterampilan (Suprijono, 2012). Hasil pembelajaran 
menurut Lindgren (Suprijono, 2012) meliputi kecakapan, informasi, pengertian, dan sikap. Hasil belajar mencakup kemampuan kognitif, afektif, dan psikomotorik (Bloom dalam Suprijono, 2012).

Degeng (dalam Wena, 2009) mendefinisikan, bahwa hasil pembelajaran adalah semua efek yang dapat dijadikan indikator tentang nilai dari penggunaan strategi pembelajaran di bawah kondisi yang berbeda. Hasil pembelajaran dapat diklasifikasikan menjadi tiga hal, yaitu: (1) keefektifan (effectiveness), (2) efisiensi (efficiency), (3) daya tarik (appeal). Wena (2009) menambahkan keefektifan pembelajaran diukur dari tingkat pencapaian siswa, efisiensi pembelajaran diukur dengan perbandingan antara keefektifan dan jumlah waktu atau biaya, dan daya tarik pembelajaran diukur dengan mengamati kecenderungan siswa untuk tetap dan terus belajar.

Dengan demikian dapat disimpulkan bahwa hasil belajar dalam penelitian ini mencakup (1) aspek afektif berupa karakter kemadirian, (2) aspek psikomotorik, berupa keterampilan pemecahan masalah, dan (3) aspek kognitif, berupa prestasi belajar siswa.

Balitbang Puskur Kemdiknas mendeskripsikan karakter mandiri adalah sikap dan perilaku yang tiidak mudah tergantung pada orang lain dalam menyelesaikan tugas-tugas. Masing-masing karakter bangsa memiliki indikator keberhasilan sekolah dan keberhasilan kelas dalam rangka pengembangan pendidikan budaya dan karakter bangsa, demikian halnya dengan nilai karakter mandiri bangsa. Indikator keberhasilan sekolah dari karakter mandiri bangsa yaitu menciptakan situasi sekolah yang membangun karakter siswa. Sedang indikator keberhasilan kelasnya adalah menciptakan suasana kelas yang memberikan kesempatan kepada siswa untuk bekerja mandiri. Data untuk hasil belajar afektif peneliti akan menggunakan pengamatan karakter kemandirian siswa dalam pembelajaran. Adapun instrumennya menggunakan pengembangan dari indikatorindikator keberhasilan karakter kemandirian bangsa.

Karakter kemandirian akan muncul karena adanya indikator, diantaranya: (1) Initiative (prakarsa); (2) Creativity (daya cipta);

Innovation (pembaharuan/penemuan baru);

Improvisation (pengembangan/ penyempurnaan); dan (5) Pro-active, pantang menyerah dalam mencari dan menemukan solusi berbagai masalah yang dihadapi (Sumahamijaya dkk, 2003).

Preisseien (Ahmadi dkk, 2011) bahwa keterampilan pemecahan masalah adalah keterampilan individu dalam menggunakan proses berpikir untuk memecahkan masalah melalui pengumpulan fakta-fakta, analisis informasi, menyusun berbagai alternatif pemecahan, dan memilih pemecahan masalah yang paling efektif.

Keterampilan pada peneilitian ini mengacu pada langkah penyelesaian yang digunakan Polya (Suherman dkk, 2003) dalam pemecahan masalah yang terdiri dari (1) keterampilan memahami masalah; (2) keterampilan membuat rencana penyelesaian; (3) Keterampialan menyelesaikan masalah sesuai rencana; (4) keterampilan pengecekan kembali semua langkah yang telah dikerjakan. Langkah inilah yang dijadikan indikator untuk mengamati keterampilan siswa dalam pemecahan masalah.

Prestasi belajar adalah kemampuankemampuan yang dimiliki oleh peserta didik setelah ia menerima pengalaman belajarnya (Sudjana, 2002). Aiken (1997) menambahkan prestasi belajar sebagai tingkat pengetahuan, keterampilan, atau capaian yang diperoleh peserta didik untuk bidang studi tertentu. Prestasi belajar seperti itu diukur melalui tes. Tes bukan hanya mengukur kemampuan individual melainkan juga untuk mengevaluasi keefektifan suatu program pembelajaran. Tes dilakukan setelah siswa mengikuti suatu program pembelajaran. Oleh karena itu, skor yang diperoleh dari tes seperti itu cenderung sebagai akibat dilakukannya proses pembelajaran bukan karena pengaruh tingkat intelegensi.

\section{METODOLOGI}

Subyek atau sampel yang akan diteliti adalah siswa yang mendapat pembelajaran dengan materi Eksponen dan Logaritma pada semester gasal kelas X.1 SMA Negeri 1 Tanjung tahun pelajaran 2014/2015 berjumlah 39 anak. Penelitian ini dilaksanakan dalam bentuk PTK 2 siklus. Pada setiap siklus memuat 4 langkah yaitu perencanaan, pelaksanaan, evaluasi dan refleksi. Penelitian ini juga dilakukan secara kolaborasi dengan teman sejawat.

Variabel yang diamati dan dites dalam penelitian ini meliputi (1) karakter kemandirian; (2) keterampilan pemecahan masalah; dan (3) prestasi belajar siswa dalam pembelajaran materi Eksponen dan 
Logaritma dengan penerapan scaffolding learning berbasis karakter kelas X.1 SMA Negeri 1 Tanjung.

Data merupakan ekspresi atau hasil pengamatan/penghitungan/pengukuran dari suatu variabel. Data dari variabel karakter kemandirian dan variabel keterampilan pemecahan masalah (KPM) siswa diambil dengan pengamatan teman sejawat, sedangkan data dari variabel prestasi belajar diambil dengan tes diakhir pembelajaran. Data yang diperoleh diolah dengan analisis deskriptif komparatif.

Data hasil pengamatan variabel karakter kemandirian dan keterampilan pemecahan masalah siswa, diolah dengan menentukan rata-rata skor pengamatan. Sedangkan data variabel prestasi belajar siswa diolah berdasarkan nilai tes dengan $\mathrm{KKM}=75$. Ketuntsan hasil belajar secara klasikal ditetapkan sebesar $85 \%$.

Rataan skor $=\frac{\text { Jumlah skor tiap indikator }}{\text { Banyaknya indikator }}$

Kriteria skor untuk pengamatan karakter kemandirian dan keterampilan pemecahan masalah ditunjukkan dalam tabel 1, sebagai berikut.

Tabel 1. Kriteria Skor Pengamatan

\begin{tabular}{|c|c|}
\hline Rataan skor & Kriteria/Predikat \\
\hline $4,30<R S \leq 5,00$ & Sangat baik \\
\hline $3,75<R S \leq 4,29$ & Baik \\
\hline $2,50<R S \leq 3,74$ & Kurang baik \\
\hline $1,00<R S \leq 2,49$ & Tidak baik \\
\hline
\end{tabular}

Kriteria penilaian prestasi belajar ditunjukkan pada tabel 2 , sebagai berikut:

Tabel 2. Kriteria Penilaian Prestasi Belajar

\begin{tabular}{|c|c|}
\hline Nilai Tes & Kriteria/Predikat \\
\hline $86 \leq N \leq 100$ & Sangat baik \\
\hline $75 \leq N \leq 85$ & Baik \\
\hline $50 \leq N \leq 74$ & Kurang baik \\
\hline $0 \leq N \leq 49$ & Tidak baik \\
\hline
\end{tabular}

Siswa dikatakan tuntas belajar apabila mencapai predikat minimal baik untuk masing-masing penilaian.

\section{HASIL DAN PEMBAHASAN}

Hasil belajar dalam penelitian ini mencakup tiga aspek, yaitu (1) hasil belajar afektif yakni karakter kemandirian siswa, (2) hasil belajar psikomotorik berupa keterampilan pemecahan masalah, dan (3) hasil belajar kognitif berupa prestasi belajar siswa pada pembelajaran dengan penerapan scaffolding learning berbasis karakter.

\section{Hasil Belajar Siklus I}

Penelitian yang dilaksanakan dalam dua siklus dengan tiap siklusnya dua kali pertemuan. Hasil belajar untuk siklus I, sebagai berikut (1) karakter kemandirian belajar siswa sebagai hasil belajar afektif pada belum sesuai dengan tolok ukur yang ingin dicapai, yakni mencapai ketuntasan klasikal 85\%. Di mana dari jumlah 39 siswa yang ada hasil baru mencapai $64,10 \%$ atau 25 siswa yang sudah mencapai indikator keberhasilan, yakni berada pada kriteria baik dan sangat baik; (2) keterampilan pemecahan masalah sebagai hasil belajar psikomotorik juga belum mencapai indikator keberhasilan yang ditentukan. Hal ini dapat dilihat dari siswa yang sudah mencapai pada kategori baik dan sangat baik sebanyak 21 siswa atau sebesar 53,85\%; dan (3) prestasi belajar sebagai hasil kognitifnya juga didapatkan hasil yang tidak jauh beda di mana siswa yang sudah mencapai KKM baru 24 orang atau ketercapaian ketuntasan klasikal sebesar 61,54\%. Dengan demikian untuk tindakan pada siklus I menghasilkan ketiga aspek hasil belajar yang belum mencapai hasil yang ditargetkan. Hasil belajar siklus I ketiganya dapat dirangkumkan pada tabel 3 , di bawah ini.

Tabel 3. Hasil Belajar Siklus I

\begin{tabular}{|l|c|c|c|}
\hline \multicolumn{1}{|c|}{$\begin{array}{c}\text { Hasil } \\
\text { Belajar }\end{array}$} & $\begin{array}{c}\text { Jumlah } \\
\text { Siswa } \\
\text { Tidak } \\
\text { Tuntas }\end{array}$ & $\begin{array}{c}\text { Jumlah } \\
\text { Siswa } \\
\text { Tuntas }\end{array}$ & $\begin{array}{c}\text { Persen } \\
\text { tase } \\
\text { Ketunt } \\
\text { asan }\end{array}$ \\
\hline Kemandirian & 14 & 25 & $64,10 \%$ \\
\hline $\begin{array}{l}\text { Keterampilan } \\
\text { Pemecahan } \\
\text { Masalah }\end{array}$ & 18 & 21 & $53,85 \%$ \\
\hline $\begin{array}{l}\text { Prestasi } \\
\text { Belajar }\end{array}$ & 15 & 24 & $61,54 \%$ \\
\hline
\end{tabular}

\section{Hasil Belajar Siklus II}

Berpedoman pada hasil yang didapatkan pada siklus I, di mana belum tercapainya tolok ukur keberhasilan yang diharapkan sebesar 85\%, maka dilakukan perbaikan-perbaikan terutama pada hal-hal yang menjadi kendala dari ketidakberhasilan tersebut. Kemudian pembelajaran dilanjutkan pada siklus II dengan memperbaiki tindakan 
dengan lebih meningkatkan perlakuan, serta mengurangi kendala yang ada sebelumnya.

Hasil belajar yang didapatkan pada tindakan siklus II sudah mencapai target keberhasilan secara klasikal yang masingmasing hasilnya dapat diuraikan, yaitu (1) Hasil karakter kemandirian siswa tercapai sebesar 89,75\% (sebanyak 35 siswa yang sudah tuntas dengan mencapai kategori baik dan sangat baik); (2) keterampilan pemecahan masalah diperoleh hasil $87,18 \%$ atau 34 siswa yang tuntas (mencapai indikator baik dan sangat baik); dan (3) prestasi belajar siswa $87,18 \%$ dengan jumlah siswa yang sudah mencapai ketuntasan belajar sebanyak 34 anak. Hasil belajar siklus II ketiganya dapat dirangkumkan pada tabel 4, di bawah ini.

Tabel 4. Hasil Belajar Siklus II

\begin{tabular}{|l|c|c|c|}
\hline \multicolumn{1}{|c|}{$\begin{array}{c}\text { Hasil } \\
\text { Belajar }\end{array}$} & $\begin{array}{c}\text { Jumlah } \\
\text { Siswa } \\
\text { Tidak } \\
\text { Tuntas }\end{array}$ & $\begin{array}{c}\text { Jumlah } \\
\text { Siswa } \\
\text { Tuntas }\end{array}$ & $\begin{array}{c}\text { Persen } \\
\text { tase } \\
\text { Ketunt } \\
\text { asan }\end{array}$ \\
\hline Kemandirian & 4 & 35 & $89,75 \%$ \\
\hline $\begin{array}{l}\text { Keterampilan } \\
\text { Pemecahan } \\
\text { Masalah }\end{array}$ & 5 & 34 & $87,18 \%$ \\
\hline $\begin{array}{l}\text { Prestasi } \\
\text { Belajar }\end{array}$ & 5 & 34 & $87,18 \%$ \\
\hline
\end{tabular}

\section{Peningkatan Hasil Belajar}

Berdasarkan hasil belajar yang diperoleh pada tiap siklusnya dapat dideskripsikan bahwa adanya peningkatan yang signifikan yang terjadi dari siklus I dan siklus II. Karakter kemandirian siswa meningkat dari $64,10 \%$ menjadi $89,75 \%$ atau peningkatan sebesar 25,65\%. Keterampilan pemecahan masalah meningkat dari 53,85\% menjadi $87,18 \%$ (peningkatan sebesar $33,33 \%$ ), dan prestasi belajar meningkat dari $61,54 \%$ menjadi $87,18 \%$ (peningkatan $25,64 \%$ ). Peningkatan hasil belajar tersebut dapat ditunjukkan dalam Gambar, sebagai berikut.

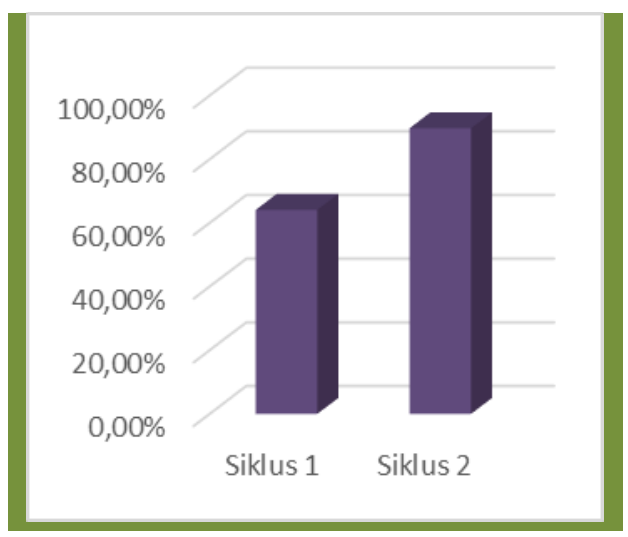

Gambar 1.

\section{Peningkatan Kemandirian Siswa}

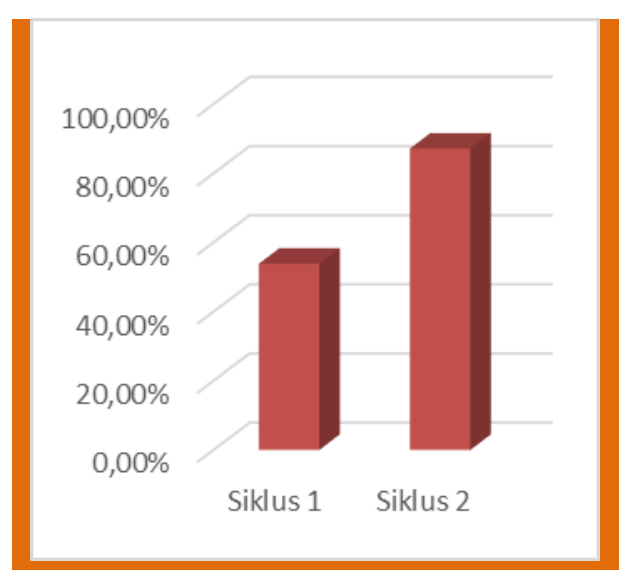

Gambar 2.

Peningkatan Keterampilan Pemecahan Masalah Siswa

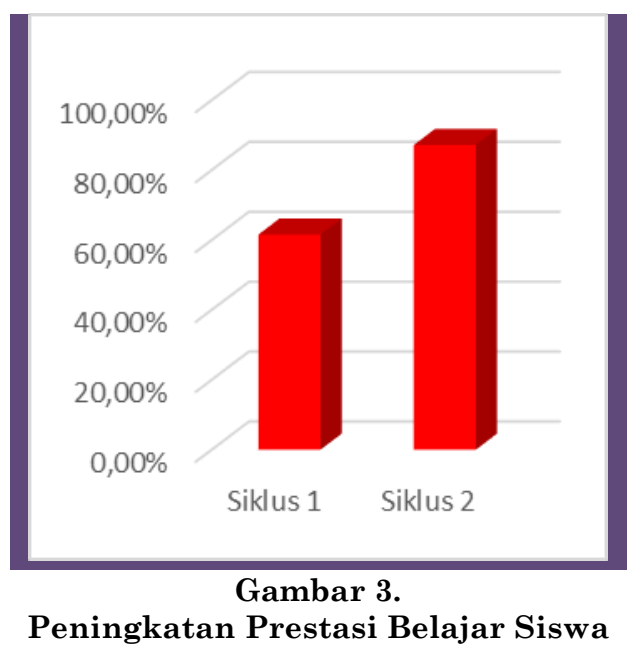

Dari hasil belajar yang sudah dideskripsikan di atas dapat diambil simpulan bahwa pembelajaran dengan penerapan scaffolding learning berbasis karakter dapat meningkatkan ketiga hasil belajar, yakni (1) karakter kemandirian siswa (penilaian afektif), (2) keterampilan pemecahan masalah (penilaian psikomotorik), dan (3) prestasi belajar (penilaian kognitif) pada materi Eksponen dan Logaritma kelas X.1 pada semester 1 SMA Negeri 1 Tanjung tahun pelajaran 2014/2015. Dengan demikian, penelitian tindakan kelas selesai dan hipotesis yang diajukan terbukti kebenarannya.

Hasil ini menguatkan hasil penelitian yang dilakukan Pramudyo dan Hardinto (2008) dengan judul "Efektivitas Penerapan Pendekatan Pembelajaran Scaffolding dalam Ketuntasan Belajar Ekonomi Siswa Kelas X SMA Labortorium Universitas Negeri Malang", dengan hasil Pendekatan pembelajaran dengan scaffolding learning efektif diterapkan untuk untuk mencapai 
ketuntasan belajar ekonomi dan dapat meningkatan prestasi belajar siswa kelas X-3 SMA Laboratorium Universitas Negeri Malang. Dan Penelitian yang dilakukan oleh Puspita dan Sapir (2012) dalam penelitiannya "Penerapan Pembelajaran Konstruktivistik Teknik Scaffolding Pada Mata Pelajaran IPS (Ekonomi) untuk Meningkatkan Hasil Belajar Ekonomi Siswa Kelas VIII - I SMPN 8 Malang", dengan hasil penerapan pembelajaran teknik scaffolding dapat meningkatkan hasil belajar siswa dan nilai rata-rata kelas. Sebelum diterapkannya pembelajaran tekhnik scaffolding dari 30 siswa didapat hasil 14 anak tuntas belajar (belum mencapai ketuntasan klasikal) dan nilai rata-rata kelas hanya 70 . Setelah diberikan penerapan pembelajaran teknik scaffolding jumlah siswa yang tuntas menjadi 28 atau 93\%, sedangkan siswa yang tidak tuntas adalah 2 orang atau $7 \%$ dengan ratarata nilai kelas meningkat menjadi 90. Hasil menggambarkan bahwa kelas VIII-I sudah mencapai ketuntasan secara klasikal karena melebihi $85 \%$.

\section{KESIMPULAN DAN SARAN}

\section{Kesimpulan}

Berdasarkan hasil dan pembahasan penelitian ini dapat disimpulkan bahwa penerapan scaffolding learning berbasis karakter dapat meningkatkan hasil belajar afektif, psikomotorik, dan kognitif siswa pada pembelajaran matematika materi Eksponen dan Logaritma dengan ketuntasan klasikal $85 \%$. Ketiga aspek hasil belajar dari siklus I dan siklus II dalam penelitian mengalami peningkatan setelah diterapkan scaffolding learning berbasis karakter pada pembelajaran matematika materi Eksponen dan Logaritma. Karakter kemandirian siswa meningkat dari $64,10 \%$, menjadi $89,75 \%$ atau peningkatan kemandirian siswa sebesar $25,65 \%$. Keterampilan pemecahan masalah siswa meningkat dari $53,85 \%$ menjadi $87,18 \%$ atau peningkatan keterampilan pemecahan masalah siswa sebesar 33,33\%. Prestasi belajar siswa juga meningkat yang ditunjukkan pada hasil pra siklus siswa yang mencapai tuntas baru 20 anak $(51,28 \%)$, siklus I menjadi 24 anak $(61,54 \%)$, dan siklus II berjumlah 34 anak $(87,18 \%)$ atau peningkatan prestasi belajar sebesar $25,64 \%$. Hasil ini menunjukkan tercapainya target indikator keberhasilan yang telah ditetapkan yakni ketuntasan klasikal sebesar 85\%.
Berdasarkan hasil yang telah dicapai dalam penelitian ini, maka peneliti dapat memberikan saran (1) penerapan scaffolding learning berbasis karakter seyogyanya dapat dijadikan media bagi siswa dalam berlatih, saling mengenal sikap, membimbing, mengembangkan keterampilan, membiasakan berpikir kritis dalam memecahkan persoalan matematika dan mampu berkarya inovatif dalam kehidupan sehari-hari; pembelajaran scaffolding berbasis karakter pada materi Eksponen dan Logaritma menjadikan wawasan dan sebagai alternatif bagi guru dalam upaya meningkatkan kemampuan dalam mengajar; (3) penelitian dengan menggunakan scaffolding learning berbasis karakter dapat dijadikan referensi dalam pengembangan inovasi pembelajaran sebagai upaya peningkatan mutu dan kinerja sekolah.

\section{DAFTAR PUSTAKA}

Ahmadi, I. K., Setyono, H. A, dan Amri, S. (2011). Pembelajaran Akselerasi (Analisis Teori dan Praktik serta Pengaruhnya terhadap Mekanisme Pembelajaran dalam Kelas Akselerasi). Jakarta: Pustaka Publisher.

Aiken, L. R. (1997). Psyikologi Testing Assessment. Boston: Allya and Bacon.

Anghileri, J. (2006). "Scaffolding Practices That Enhance Mathematics Learning". Journal of Mathematics Teacher Education. (2006) 9. Hal 33-52.

Balitbang Puskur Kemendiknas. 2011. Direktorat Pembinaan SMA Ditjen Pendidikan Menengah Konsep dan Implementasi Pendidikan Karakter di SMA. Jakarta: Departemen Pendidikan Nasional. Dirjen Manajemen Pendidikan Dasar dan Menengah.

Dimyati dan Mudjiono. (1999). Belajar dan Pembelajaran. Jakarta: Rineka Cipta.

Herbst, P.G. 2006. "Teaching Geometry with Problems: Negotiating Instructional Situation and Mathematical Tasks". Journal for Research in Mathematics Education, Volume 37, No. 4. Hal 313347.

Sagala, S. 2006. Konsep dan Makna Pembelajaran. Bandung: CV Alfabeta.

Sudjana. (2002). Metoda Statistika. Bandung: Tarsito.

Suherman, E., dkk. (2003). Strategi Pembelajaran Matematika Kontemporer. Bandung: IMSTEP. 
Sumahamijaya, S., Yasben, D., dan Dana, D,

A. (2003). Pendidikan Karakter Mandiri

dan Kewiraswastaan Suatu Upaya Keberhasilan Program Pendidikan Berbasis Luas / Broad Based Education and Life Skills. Bandung: Angkasa.

Suprijono, A. (2012). Cooperative Learning Teori dan Aplikasi PAIKEM. Yogyakarta: Pustaka Pelajar.

Suyitno, dan Amin. (2004). Dasar-dasar dan Proses Pembelajaran Matematika I.

Semarang: Jurusan Matematika FMIPA UNNES).

Wena, M. (2009). Strategi Pembelajaran Inovatif Kontemporer Suatu Tinjauan Konseptual Operasional. Jakarta: Bumi Aksara. 